\title{
HUBUNGAN POWER OTOT TUNGKAI TERHADAP KETERAMPILAN SHOOTING FUTSAL DI SMP NEGERI 15 KOTA BENGKULU
}

\author{
Apriman Saleh ${ }^{1, a)}$, Martiani) \\ 1)Program studi Pendidikan Jasmani Universitas Dehasen Bengkulu \\ ${ }^{a)}$ Corresponding Author: aprimansaleh@gmail.com
}

\begin{abstract}
The aim of this study is to find out the correlation between leg muscle power towards futsal shooting skills at SMPN 15 of Bengkulu City. It is seen that the students' shooting skills were not capable enough so when the shooting was done, it rarely enters the opponent's goal. This problem is caused by several factors, including the low level of leg muscle power of students at SMP Negeri 15 of Bengkulu city. The research method of this study is a correlation method. The population of this study were 20 students who are also futsal players while the sampling technique used was the total sampling, moreover the place for conducting research was in SMP 15 of Bengkulu city, while the research schedule was in March 2019. Leg muscle power data was taken by vertical jump test, and then the data of shooting skill was taken with a shooting test on goal. The data analysis technique of this study uses correlation analysis techniques. The results show that: There is a significant correlation between leg muscle power $(X)$ towards the shooting skills in futsal game of the students in $S M P N 15$ of Bengkulu city, with value of rxy $=0.92>r(0.05)(19)=0.444$
\end{abstract}

Keywords: Leg Muscles Power, Shooting Skills

Tujuan penelitian ini untuk mengetahui hubungan power otot tungkai terhadap keterampilan shooting futsal di SMP Negeri 15 Kota Bengkulu. bahwa keterampilan shooting para siswa kurang maksimal sehingga pada shooting bola jarang masuk ke gawang lawan. Masalah ini disebabkan oleh beberapa faktor, antara lain rendahnya tingkat power otot tungkai siswa SMP Negeri 15 Kota Bengkulu. Metode penelitian ini adalah metode korelasional. Populasi penelitian ini seluruh pemain futsal SMP 15 sebanyak 20 orang sedangkan pengambilan sampel menggunakan teknik total sampling, Tempat pelaksanaan penelitian di lapangan SMP 15 Kota Bengkulu, adapun waktu penelitian adalah bulan maret 2019. Data power otot tungkai diambil dengan tes vertical jump, dan data keterampilan shooting diambil dengan tes shoot ke gawang. Teknik analisis data penelitian ini menggunakan teknik dengan analisis korelasi. Hasil analisis data menunjukkan bahwa: Terdapat hubungan yang signifikan antara power otot tungkai (X) terhadap keterampilan shooting pada siswa futsal di SMP 15 Kota Bengkulu, dengan nilai $r_{x y}=0,92>r_{(0,05)(19)}=0,444$

Kata kunci: Power Otot Tungkai, Keterampilan shootin

\section{Pendahuluan}

Pendidikan jasmani dan olahraga pada hakikatnya adalah proses pendidikan yang memanfaatkan aktifitas fisik. Pendidikan jasmani dan olahraga merupakan bagian yang tak terpisahkan dari pendidikan umum. Olahraga merupakan suatu bidang ilmu yang mempunyai kedudukan yang sangat penting dalam dunia 
pendidikan. Pendidikan jasmani diajarkan di sekolah mempunyai peranan penting untuk memberikan kesempatan kepada peserta didik untuk terlibat langsung dalam berbagai pengalaman belajar melalui aktivitas jasmani, olahraga dan kesehatan yang terpilih yang dilakukan secara sistematis. Pendidikan sebagai suatu proses pembinaan manusia yang berlangsung seumur hidup, hal ini pula yang menjadikan pendidikan olahraga berperan dalam membangun karakter suatu bangsa.

Olahraga merupakan sarana, bukan hanya di Indonesia di negara-negara lainpun setiap orang meluangkan waktu untuk melakukan melakukan aktivitas jasmani, ini terbukti bahwa olahraga juga sudah menjadi gaya hidup untuk menuju kehidupan yang sehat. Olahraga sudah menjadi sebuah gaya hidup bagi sebagian orang, bahkan untuk sebagian orang yang lain olahraga menjadi sebuah kebutuhan mendasar dalam hidup. Olahraga mempunyai fungsi dan manfaat sesuai dengan kebutuhan, selain olahraga sebagai sarana rekreasi, olahraga juga dapat pula sebagai prestasi.

Olahraga menjadi sangat penting karena tidak terlepas dari kebutuhan mendasar manusia itu sendiri yang pada prinsipnya selalu bergerak. Olahraga itu sendiri merupakan serangkaian gerak raga yang teratur dan terencana untuk memelihara dan meningkatkan kemampuan gerak yang bertujuan untuk mempertahankan hidup serta meningkatkan kualitas hidup seseorang. Tujuan seseorang berolahraga adalah untuk meningkatkan kesehatan yang menyeluruh baik jasmani maupun rohani.

Peningkatkan prestasi perlu diadakan karena adanya dorongan dari dukungan beberapa pihak, di sekolah salah satunya yang sangat berperan dalam meningkatkan prestasi adalah guru. Pembinaan prestasi baik di ekstrakurikuler yang berperan untuk meningkatkan presatasia dalah pelatih. Olahraga juga mempunyai peranan yang sangat penting untuk membantu tercapainya kebugaran jasmani. Penerapkan batasan pendidikan jasmani, harus pula dipertimbangkan kaitannya dengan permainan, olahraga serta prestasi. Permainan menjadi aktivitas bermain, terutama merupakan aktivitas kegembiraan. Pembekalan pengalaman belajar pendidikan jasmani diarahkan untuk membina pertumbuhan kondisi fisik dan pengembangan mental yang lebih baik, sekaligus membentuk pola hidup yang sehat.
Kegiatan olahraga yang mengarah ke prestasi menjadi suatu alasan seseorang menekuni olahraga. Olahraga merupakan kegiatan sistematis yang dapat mendorong seseorang dalam membina serta mengembangkan potensi jasmani dan rohani. Sejalan dengan perkembangan dan peningkatan fisik yang beranjak matang maka perkembangan motorik sudah dapat terkoordinasi dengan baik dari tingkat anak-anak, remaja bahkan ke tingkat dewasa. Usia anak didik ditingkat sekolah dasar merupakan masa yang ideal untuk belajar keterampilan yang berkaitan dengan motorik ini, seperti halnya dengan bermain futsal.

Olahraga futsal merupakan olahraga yang dimainkan oleh lima orang termasuk penjaga gawang dan biasanya dimainkan di dalam suatu ruangan. Seperti halnya dengan olahraga sepakbola, futsal juga olahraga yang memiliki minat yang banyak oleh kalangan masyarakat, dikarenakan olahraga ini dapat dimainkan disemua lapisan masyarakat baik kalangan atas maupun kalangan bawah. Futsal merupakan cabang olahraga yang popular dan digemari oleh seluruh lapisan masyarakat terutama kaum laki-laki mulai dari anak-anak, remaja dan dewasa.

Dari beberapa penjelasan mengenai teknik dasar yang ada di atas, teknik shooting merupakan salah satu teknik yang harus dikuasi oleh setiap pemain futsal. Shooting merupakan salah satu teknik yang selalu digunakan pemain untuk mencetak gol sebanyak-banyaknya kegawang lawan. Setiap pemain dalam melakukan shooting harus selalu ditingkatkan guna untuk menghasilkan gol untuk memenangi pertandingan.

Selain keterampilan shooting, otot dalam aktivitas olahraga dapat disebutkan sebagai motor pengerak dalam setiap aktivitas gerak yang dilakukan guna untuk mendapatkan hasil yang ingin dicapai dan proses pencapaian prestasi semaksimal mungkin. Maka dari itu olahraga futsal sangat membutuhkan power otot baik itu kekuatan otot tungkai pada waktu melakukan shooting. Power dalam melakukan melakukan shooting memiliki faktor yang sangat dominan pada saat bermain futsal. Untuk mendapatkan kualitas shooting yang baik sangat membutuhkan latihan fisik yang terprogram dan dengan bimbingan pelatih untuk mengarahkan bagiamana dapat menghasilkan kekuatan otot tungkai untuk dapat melakukan shooting yang terarah dengan teknik yang benar. 
Berdasarkan dari beberapa penjelasan di atas dan dalam kaitannya futsal yang ada di SMP Negeri 15 Kota Bengkulu sudah baik, namun perlu adanya peningkatan kembali mengenai keterampilan shooting, hal ini berkaitan dengan power otot yang masih kurang kuat dan seimbang. Hal ini dikarenakan pada saat melakukan shooting masih terlalu lemah dan terlalu mudah diantisipasi oleh penjaga gawang lawan. Olahraga futsal ini dibutuhkan akselerasi tubuh yang kuat karena bukan saja otot yang digunakan, namun keterampilan dasarpun harus dimiliki oleh setiap pemain, baik keterampilan dribbling, shooting, passing, controlling untuk mencapai suatu kemenangan.

Berdasarkan dari hasil pengamatan yang peneliti lakukan di SMP Negeri 15 Kota Bengkulu, dan beberapa permasalahan yang muncul maka peneliti mengajukan sebuah judul untuk melakukan penelitian yaitu "Hubungan Power Otot Tungkai Terhadap Keterampilan Shooting Futsal di SMP Negeri 15 Kota Bengkulu".

Olahraga futsal merupakan suatu aktifitas olahraga yang dimainkan di dalam suatu ruangan ataupun di luar ruangan. Cabang olahraga futsal ini juga memiliki keunggulan, yaitu lapangan tidak luas, dimainkan oleh 5 pemain termasuk kiper dan memakai bola ringan, serta memiliki minat yang banyak oleh kalangan masyarakat, dikarenakan olahraga ini dapat dimainkan dari semua lapisan masyarakat baik pelajar ataupun mahasiswa, dari kalangan atas maupun kalangan bawah, baik anak kecil sampai tingkat yang lebih dewasa.

Sutanto (2016:132) menjelaskan, "Permainan futsal dipopulerkan oleh Juan Carlos Ceriani di Montevideo, Uruguay, tahun 1930". Saat itu permainan baru tersebut diberi nama futebol de salao (bahasa Portugis) atau fubol sala (bahasa Spanyol) dengan makna yang sama, yaitu sepakbola ruangan. Dari kedua bahasa tersebut munculah istilah baru, yaitu futsal.

Kegiatan ekstrakurikuler merupakan kegiatan pengayaan dan perbaikan yang berkaitan dengan program kokurikuler dan intrakurikuler. Kegiatan ini dapat dijadikan sebagai wadah bagi siswa yang memiliki minat mengikuti kegiatan tersebut. Melalui bimbingan dan pelatihan guru, kegiatan ekstrakurikuler dapat membentuk sikap positif terhadap kegiatan yang diikuti oleh para siswa.

Berdasarkan Peraturan Menteri Pendidikan Nasional Republik Indonesia Nomor 39 Tahun 2008 tentang Pembinaan Kesiswaan (2008: 4), kegiatan ekstrakurikuler merupakan salah satu jalur pembinaan kesiswaan. Kegiatan ekstrakurikuler yang diikuti dan dilaksanakan oleh siswa baik di sekolah maupun di luar sekolah, bertujuan agar siswa dapat memperkaya dan memperluas diri.

Otot merupakan alat penggerak aktif karena mampu berkontraksi dan berfungsi menggerakkan organ-organ tertentu dalam tubuh. Menurut Rika (2015:42-43), "Otot memiliki tiga kemampuan khusus, yaitu:

Kontraktibilitas: Kemampuan untuk berkontrkasi/memendek

Ekstensibilitas: Kemampuan untuk melakukan gerakan kebalikan dari gerakan yang ditimbulkan saat kontraksi

Elastisitas: Kemampuan otot untuk kembali pada ukuran semula setelah berkontraksi. Saat kembali pada ukuran semula otot disebut dalam keadaan relaksasi.

Shooting merupakan salah satu teknik dasar dari permainan futsal yang sangat penting dimiliki oleh seorang pemain. Shooting merupakan suatu usaha untuk memindahkan bola ke sasaran dengan menggunakan kaki ke arah gawang. Dalam permainan futsal shooting dilakukan dengan keras dan sekuat tenaga. Menurut Mulyono (2017:42) dalam melakukan shooting yang pertama kali dilakukan adalah kemana arah bola yang akan ditendang. Shooting umumnya dilakukan untuk menciptakan gol. Menendang bola dapat dilakukan dalam keadaan bola diam, menggelinding, maupun melayang di udara yang tujuannya memasukkan bola ke dalam gawang lawan. Kunci kekuatan shooting ada pada kekuatan tungkai kaki dan sudut pengambilan tendangan yang optimal

\section{Metode Penelitian}

Penelitian pada dasarnya adalah suatu kegiatan ilmiah untuk memperoleh pengetahuan yang benar tentang suatu masalah (Rachmat, 2015:15). Metode penelitian yang digunakan dalam penelitian ini adalah dengan menggunakan metode korelasional (correlational researc. Sukardi, (2016:53) menjelaskan "Populasi adalah elemen penelitian yang hidup dan tinggal bersama-sama dan secara teoritis menjadi target hasil penelitian". Populasi dalam penelitian ini yaitu seluruh pemain futsal di SMP Negeri 15 Kota Bengkulu yang berjumlah 20 orang.

Sebagian jumlah populasi yang dipilih untuk sumber data disebut sampel (Sukardi, 
2016:54). Sampel yang digunakan dalam penelitian ini adalah dengan menggunakan total sampling. Dimana seluruh populasi dijadikan sampel yaitu berjumlah 20 orang.

\section{Hasil Penelitian}

Sesuai dengan rancangan penelitian dan studi kepustakaan yang telah dikemukan terdahulu, analisis data dilakukan terhadap hasil tes kedua variabel. Kedua variabel tersebut adalah Power otot tungkai sebagai variabel bebas dan keterampilan shooting Pada atlet futsal SMP 15 Kota Bengkulu sebagai variabel terikatnya. Selanjutnya akan dijabarkan hasil dari penelitian sebagai berikut:

Daya Ledak otot Tungkai Dari hasil pengukuran Power Otot Tungkai yang dilakukan terhadap atlet Futsal SMP 15 Kota Bengkulu didapat skor tertinggi 47 dan skor terendah 31 berdasarkan data tersebut rata-rata hitung (mean) 36.8. Langkah awal, tentukan banyak kelas dengan rumus $1+3.3 \log 20$ (sampel) $=5.29$, dapat di bulatkan menjadi 5, dan mencari panjang kelas dengan rumus nilai tertinggi dikurang nilai terendah di bagi banyak kelas adalah $47-31=16: 5=3.2$ di bulatkan jadi 3 Distribusi kategori Power otot tungkai yang dilakukan terhadap atlet SMP 15 Kota Bengkulu dapat dilihat pada tabel berikut:

Tabel 1. Distribusi Frekuensi Power Otot Tungkai

\begin{tabular}{|c|c|c|c|}
\hline No & Kelas Interval & Frekuensi Absolut & Frekuensi Relatif \\
\hline 1. & $31-34$ & 8 & $40 \%$ \\
\hline 2. & $35-38$ & 6 & $30 \%$ \\
\hline 3. & $39-42$ & 2 & $10 \%$ \\
\hline 4. & $43-46$ & 3 & $15 \%$ \\
\hline 5. & $47-50$ & 1 & $5 \%$ \\
\hline
\end{tabular}

Dari tabel di atas dapat disimpulkan bahwa dari 20 atlet futsal SMP 15 Kota Bengkulu. Sebanyak 8 orang atlet (40\%) memiliki kategori nilai 35-38. sebanyak 6 orang atlet 30\% memiliki kategori nilai 35-38. Sebanyak 2 atlet $10 \%$ memiliki kategori nilai 39-42 Sebanyak 3 orang atlet $15 \%$ memiliki kategori nilai 43-46. Sebanyak 1 orang atlet $5 \%$ memiliki kategori nilai 47-50. dapar dilihat grafik di bawah ini

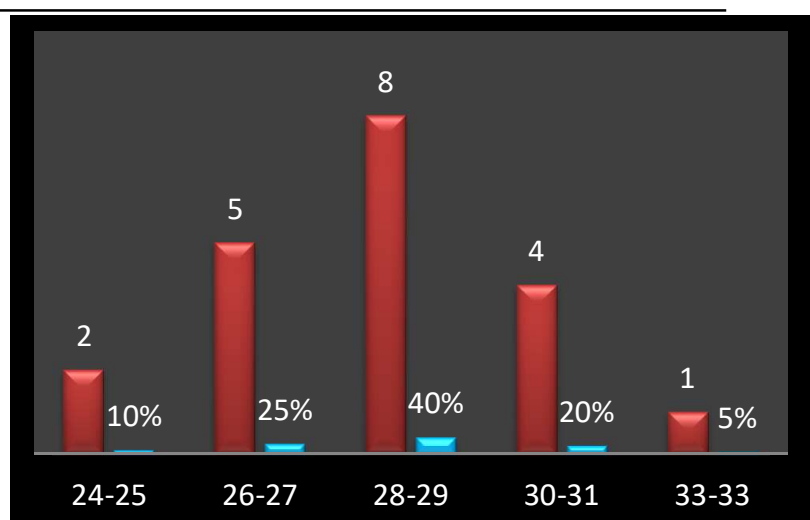

Gambar 1. Grafik power otot tungkai

Dari hasil pengukuran Shooting yang dilakukan terhadap atlet Futsal SMP 15 Kota Bengkulu terdapat skor tertinggi 33 dan skor terendah 24 , berdasarkan data tersebut rata-rata hitung (mean) 28. Langkah awal, tentukan banyak kelas dengan rumus $1+3.3$ log 30 (sampel) $=5.29$, dapat di bulatkan menjadi 5, dan mencari panjang kelas dengan rumus nilai tertinggi dikurang nilai terendah di bagi banyak kelas adalah $33-24=2: 5=1.8$ di bulatkan jadi 2 Distribusi kategori keterampilan shooting yang dilakukan atlet SMP 15 Kota Bengkulu dapat dilihat pada tabel berikut:

Tabel 2. Distribusi Frekuensi Hasil Tes Keterampilan Shooting (Y).

\begin{tabular}{|c|c|c|c|}
\hline No & $\begin{array}{c}\text { Kelas } \\
\text { Interval }\end{array}$ & Frekuensi Absolut & Frekuensi Relatif \\
\hline 1. & $24-25$ & 2 & $10 \%$ \\
\hline 2. & $26-27$ & 5 & $25 \%$ \\
\hline 3. & $28-29$ & 8 & $40 \%$ \\
\hline 4. & $30-31$ & 4 & $20 \%$ \\
\hline 5. & $33-33$ & 1 & $5 \%$ \\
\hline
\end{tabular}

- Dari tabel di atas dapat disimpulkan bahwa dari 20 atlet futsal SMP 15 Kota Bengkulu. Sebanyak 2 orang atlet $10 \%$ memiliki kategori nilai 24-25 Sebanyak 5 orang atlet (25\%) memiliki kategori nilai 26-27. sebanyak 8 orang atlet $40 \%$ memiliki kategori nilai $28-29$. Sebanyak 4 atlet 20\% memiliki kategori nilai 30-31. Sebanyak 1 orang atlet 5\% memiliki kategori nilai 33-33. 


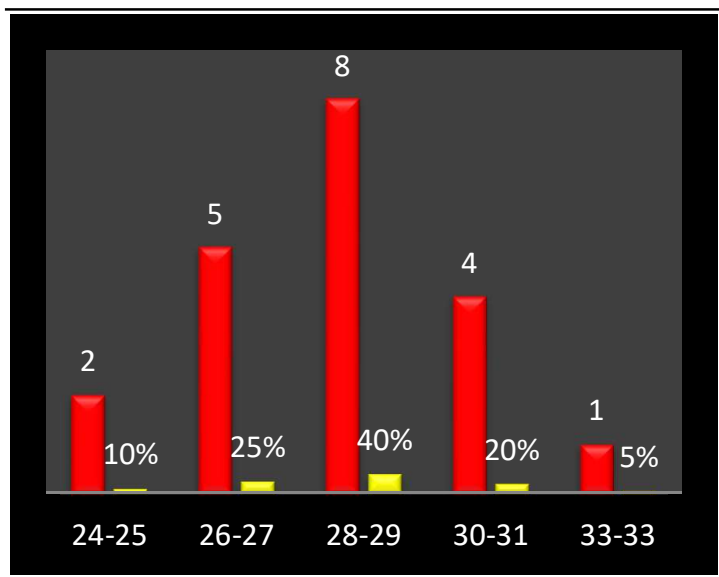

Gambar 2. Grafik keterampilan shooting

Sebelum melakukan pengujian hipotesis yang diajukan dalam penelitian ini, maka terlebih dahulu dilakukan uji prasyarat analisis data yaitu uji normalitas data. Dalam uji normalitas data ini peneliti menggunakan uji normalitas data lilliefors. Adapun hasil analisis dapat dilihat pada tabel di bawah ini :

Tabel 3. Uji Normalitas Data Variabel X dan Y

\begin{tabular}{|c|l|c|c|c|}
\hline No & \multicolumn{1}{|c|}{ Variabel } & L hitung & $\mathbf{L}$ tabel & Keterangan \\
\hline 1. & Power otot tungkai & $\mathbf{0 . 1 5 9 6}$ & $\mathbf{0 . 1 9 0}$ & Normal \\
\hline 2. & Keterampilan Shooting & $\mathbf{0 . 1 5}$ & $\mathbf{0 . 1 9 0}$ & Normal \\
\hline
\end{tabular}

Dari tabel di atas menunjukan bahwa hasil pengujian untuk power Otot Tungkai (X) skor $\mathrm{L}_{\text {hitung }} \mathbf{0 . 1 5 9 6}$ dengan $\mathrm{n}=20$ sedangkan $\mathrm{L}_{\text {tabel }}$ pada taraf signifikan 5\% atau 0,05 diperoleh 0,190. Karena $\mathrm{L}_{\text {hitung }}$ lebih kecil dari $\mathrm{L}_{\text {tabel }}$ sehingga dapat disimpulkan bahwa skor yang diperoleh dari vertical jump berdistribusi normal. Selain itu tabel tersebut di atas juga menunjukan bahwa hasil pengujian untuk keterampilan shooting (Y) skor $\mathrm{L}_{\text {hitung }}=\mathbf{0 . 1 5}$ dengan $\mathrm{n}=20$, sedangkan $\mathrm{L}_{\text {tabel }}$ pada taraf signifikan $5 \%$ atau 0,05 diperoleh 0,190. Karena $\mathrm{L}_{\text {hitung }}$ lebih kecil dari pada $\mathrm{L}_{\text {tabel }}$ sehingga dapat disimpulkan bahwa skor yang diperoleh dari keterampilan shooting berdistribusi normal.

Uji prasyarat analisis data setelah melakukan uji normalitas data maka dilakuakan uji homogenitas data dengan menggunakan uji varians (uji $\mathrm{F}$ dari Hevley) dapat di lihat pada tabel berikut ini:

Tabel. 4. Uji Homogenitas Data Variabel X dan Y

\begin{tabular}{|c|l|l|c|c|c|}
\hline No & \multicolumn{1}{|c|}{ Variabel } & Varians & F hitung & F tabel & Ket \\
\hline 1 & Power Otot Tungkai & $\mathbf{5 . 0 6}$ & \multirow{2}{*}{2.18} & \multirow{2}{*}{4,41} & Homogen \\
\hline 2 & Keterampilan Shooting & $\mathbf{2 . 3 1}$ & 2.1 & \\
\hline
\end{tabular}

Dari tabel di atas menunjukan bahwa hasil pengujian varians untuk Daya ledak Otot Tungkai (X) didapat skor 5.06, sedangkan hasil pengujian varians untuk keterampilan shooting $(\mathrm{Y})$ didapat skor 2.31 sehinggga didapat $F_{\text {hitung }}$ dengan menggunakan uji $\mathrm{F}$ dari Hevley diperoleh skor 2.18. Sedangkan untuk nilai $\mathrm{F}_{\text {tabel }}$ dengan tarap signifikan $5 \%$ atau 0,05 adalah $=4,41$ karena $F_{\text {hitung }}(2.18)$ lebih kecil dari $F_{\text {tabel }}(4,41)$ maka data dapat disimpulkan bahwa skor yang diperoleh untuk Power otot tungkai (X) terhadap keterampilan shooting (Y) memiliki data yang homogen.

Analisis data penelitian yang digunakan untuk menguji hipotesis terdiri atas analisis korelasi sederhana. Hipotesis dalam penelitian ini adalah "Ada hubungan yang signifikan antara Power otot tungkai terhadap keterampilan shooting pada atlet Futsal SMP 15 Kota Bengkulu". Hasil uji hipotesis dengan menggunakan analisis koefisien korelasi product moment dapat dilihat pada tabel berikut ini:

Tabel 5. Koefisien Korelasi Variabel (X) Terhadap Variabel (Y).

\begin{tabular}{cccc}
\hline Korelasi & rhitung & $\mathrm{r}_{\text {tabel }}$ & Keterangan \\
\hline rxy & 0,92 & 0,444 & Signifikan \\
\hline
\end{tabular}

Berdasarkan hasil analisis tersebut di atas diperoleh koefisien korelasi power otot tungkai terhadap keterampilan shooting atlet futsal Akademi sebesar 0,92 bernilai positif, artinya semakin besar skor yang diperoleh maka semakin kuat hubungan antara kedua variabel. Uji keberartian koefisien korelasi tersebut dilakukan dengan cara harga $\mathrm{r}_{\text {hitung }}$ dengan $\mathrm{r}_{\text {tabel }}$ pada $\alpha=5 \%$ dengan $\mathrm{N}=20$ diperoleh $\mathrm{r}_{\text {tabel }}$ sebesar 0,444 Karena koefisien korelasi antara $r_{x . y}=0,92$ $>\mathrm{r}_{(0,5)(20)}=0,444$ berarti hubungan power otot tungkai terhadap keterampilan shooting atlet futsal SMP 15 Kota Bengkulu adalah signifikan. Dengan demikian hipotesis yang berbunyi "ada hubungan yang kuat antara power otot tungkai terhadap keterampilan shooting atlet futsal SMP 15 Kota Bengkulu", diterima. Artinya ada hubungan power otot tungkai terhadap keterampilan shooting atlet futsal SMP 15 Kota Bengkulu

\section{Pembahasan}

Shooting merupakan salah satu teknik dasar dari permainan futsal yang sangat penting dimiliki oleh seorang pemain. Shooting merupakan menendang bola sekuat mungkin ke sasaran mengunakan kaki. Menurut Mulyono 
(2017:42) dalam melakukan shooting yang pertama kali dilakukan adalah kemana arah bola yang akan ditendang. Shooting umumnya dilakukan untuk menciptakan gol. Menurut Sutrisno (2009:5) keberhasilan mencetak gol ditentukan oleh beberapa faktor penentu. Pertama adalah kemampuan seseorang menembak dengan kuat dan tepat menggunakan kedua belah kaki kari atau kanan. Kedua, kualitas seperti antisipasi, kemantapan, dan ketenagan di bawah tekanan lawan.

Berdasarkan hasil penelitian menunjukan bahwa ada hubungan yang signifikan antara power otot tungkai terhadap keterampilan shooting atlet futsal SMP 15 Kota Bengkulu, dengan nilai rx.y $=0,92>r(0,05)(20)=0,444$. Dari hasil penelitian ini shooting merupakan salah satu teknik yang sangat penting dalam permainan futsal. Teknik dasar shooting ini merupakan cara untuk menciptakan gol. Ini disebabkan seluruh pemain memiliki kesempatan untuk menciptakan gol dan memenangkan pertandingan atau permainan. Shooting dapat dibagi menjadi dua teknik, yaitu shooting menggunakan punggung kaki dan danujung sepatu atau ujung kaki. karena shooting adalah tembakan ke gawang yang menentukan kemenangan yang akan kita dapatkan. Selain keterampilan shooting, power otot tungkai dalam futsal dapat disebutkan sebagai poin yang penting dalam melakukan shooting yang cepat dalam setiap aktivitas shooting Power otot tungkai adalah komponen yang sangat penting untuk meningkatkan kondisi fisik secara keseluruhan. Power otot merupakan salah satu unsur kondisi fisik yang memiliki peranan penting dalam kegiatan olahraga khusunya olahraga futsal, baik sebagai unsur pendukung dalam suatu gerak tertentu maupun unsur utama dalam upaya pencapaian teknik gerak yang sempurna. Otot yang kuat ternyata berpengaruh terhadap kecepatan gerak. Otot yang lebih kuat bergerak atau bereaksi lebih cepat dari pada otot yang lemah.

Shooting yang tepat dan cepat membutuhkan latihan power otot tungkai yang terprogram dan dengan bimbingan pelatih untuk mengarahkan bagiamana dapat menghasilkan shooting yang terarah dengan teknik yang benar dan cepat. Dari penjelasan di atas dapat disimpulkan bahwa salah satu tahapan yang harus dilakukan didalam melakukan shooting harus memiliki power otot tungkai yang bagus. Pernyataan inilah yang menjadikan dasar bahwa power otot tungkai sangat dibutuhkan dalam melakukan shooting dalam permainan futsal. Dengan power otot tungkai yang besar maka persentase keberhasilan dalam melakukan shooting akan semakin tinggi

\section{Kesimpulan}

Berdasarkan hasil penelitian dan pembahasan, maka didapat kesimpulan sebagai berikut : Terdapat hubungan yang signifikan antara power otot tungkai (X) terhadap keterampilan shooting. pada atlet futsal di SMP 15 Kota Bengkulu, dengan nilai $r_{x y}=0,92>$ $r_{(0,05)(20)}=0,444$.

\section{Daftar Pustaka}

Arikunto, Suharsimi. 2006. Prosedur Penelitian. Jakarta: Asdi Mahasatya.

Depdiknas. 2000. Pedoman Dan Modul Pelatihan Kesehatan Olahraga Bagi Pelatih Olahraga Pelajar. Jakarta.

Falensia Kurnia Juli Pratiwi. 2016. Hubungan Minat Dan Motivasi Dengan Keterampilan Futsal Remaja Putri Di Bandar Lampung (Skripsi Publis).

FIFA. 2015. Futsal Laws Of The Game.

Lhaksana, Justinus. 2012. Taktikdan Strategi Futsal Modern. Jakarta: Be Champion.

Lhaksana, Justinus dan Ishak H. Pordasi. 2017. Inspirasi dan Spirit Futsal. Jakarta: Raih Asa Sukses.

Lubis, Johansyah. 2013. Panduan Praktis Penyusun Program Latihan. Jakarta: PT RajaGrafindo Persada.

McGinnis, Peter M. 2010. Terjemahan Biomechanics of Sport And Exercise. Jakarta: UNJ

Mielke, Danny. 2007. Dasar-dasar Sepakbola. Bandung: Pakar Raya.

Mulyono, Muhammad Asriady. 2017. Buku Pintar Panduan Futsal. Jakarta Timur: Anugrah.

Nawawi, Umar. 2013. Anatomi Tubuh Manusia. Padang: FIK UNP.

Nirwandi. 2013. Buku Ajar Anatomi. Padang: FIK UNP.

Trijono, Rahmad. 2015. Metodologi Penelitian Kuantitatif. Depok Timur: Papas Sinar Sinanti

Sajoto. 1988. Pembinaan Kondisi Fisik Dalam Olahraga. Jakarta: Depdikbud.

Sepriani, Rika. 2015. Buku Ajar Anatomi Tubuh Manusia. Padang: FIK UNP. 
Sukadiyanto dan Dangsina Muluk. 2011. Melatih Fisik. Bandung: CV. Lubuk Agung.

Sukardi. 2016. Metodologi Penelitian Pendidikan. Jakarta: PT Bumi Aksara.

Sutanto, Teguh. 2016. Buku Pintar Olahraga. Yogyakarta: Pustaka Baru Press.

Sutrisno. 2009. Teknik Dasar-Dasar Sepakbola. Padang: FIK UNP.

Sutarmin. 2015. Belajar Futsal. Tanggerang: PT Pantja Simpati.

Tangkudung, James dan Wahyuningtyas Puspitorini. 2012. Kepelatihan Olahraga "Pembinaan Prestasi Olahraga". Jakarta: Cerdas Jaya.

Vinsencius Budi Wicaksono. 2013. Kemampuan Power Otot Tungkai, Kekuatan Otot Tungkai, dan Kelincahan Siswa yang Mengikuti Ekstrakurikuler Sepakbola dan Futsal di SMP Negeri 3 Godean (Skripsi Publis).

Widiastuti. 2017. Tes dan Pengukuran Olahraga. Jakarta: PT Bumi Timur Jaya 